\title{
"No, We're Not Culturally Ready for That Yet": Chilean Heterosexual Women's Discourses on Lesbian and Gay Parenting
}

\section{"No, Todavía No Estamos Culturalmente Preparados para Eso": Discursos de Mujeres Heterosexuales Chilenas sobre la Parentalidad Lésbica y Gay}

\author{
Víctor Figueroa \\ Universidad UNIACC \\ Fiona Tasker \\ Birkbeck, University of London
}

\begin{abstract}
This study examined Chilean heterosexual women's discourses concerning lesbian and gay (LG) parenting following a social constructionist perspective. Data from a convenience sample of 15 first-year psychology female students attending an evening university program in Concepción, Chile, were collected through 3 focus groups. Findings through a thematic analysis indicated that the major concern participants reported was that children of same-gender couples would be discriminated, because of their parents' sexual identity. A minority of participants expressed that having LG parents could disrupt a child's gender and sexual identity development. It is concluded that children in LG parented families are still regarded at best as potentially vulnerable to secondary prejudice and at worst at risk of gender and sexual identity disruption. It would be worthwhile training Chilean psychology students about the development of children of LG parents and also highlighting subtle and enacted forms of sexual stigma.
\end{abstract}

Keywords: parenting, heterosexual, lesbian, gay, Chile

\begin{abstract}
Este estudio examinó los discursos de mujeres heterosexuales chilenas sobre la parentalidad lésbica y gay (LG), siguiendo una perspectiva construccionista social. Los datos de una muestra por conveniencia de 15 estudiantes mujeres de primer año de psicología que asistían a un programa universitario vespertino en Concepción, Chile, se recopilaron a través de 3 grupos focales. Los hallazgos del análisis temático indicaron que la principal preocupación que informaron las participantes fue que los/as niños/as de parejas del mismo género serían discriminados/as, debido a la identidad sexual de sus madres/padres. Una minoría de las participantes expresó que tener madres/padres del mismo género podría perturbar el desarrollo del género y la identidad sexual de un/a niño/a. Se concluye que los/as niños/as en familias de madres lesbianas y padres gay todavía se consideran, en el mejor de los casos, como potencialmente vulnerables a los prejuicios secundarios y, en el peor, en riesgo de perturbación de la identidad sexual y de género. Sería beneficioso entrenar a estudiantes de psicología chilenos/as acerca de la parentalidad LG y también destacar formas sutiles y explícitas de estigma sexual.
\end{abstract}

Palabras clave: parentalidad, heterosexual, lésbica, gay, Chile

At the beginning of the $21^{\text {st }}$ century, men's and women's homosexuality was still represented as a disease and blameworthy "sin" by mass media and in the political sphere in Chile (Contardo, 2011). As a result, the achievement of equal rights for lesbian, gay, bisexual, transsexual or queer (LGBTQ) people has been slower in Chile than in other South American countries (Encarnación, 2011; Jones \& Vaggione, 2013). For example, same-sex marriage and same-sex adoption have been legalised in Argentina, Brazil, Colombia and Uruguay, and Ecuador recently (2019) approved same-sex marriage, through its higher court, while in Chile samegender couples do not have the right to marry and adopt children as a couple yet.

The campaigns of the LGBTQ movement to achieve a more egalitarian legal context were largely unsuccessful until 2012, when the Inter-American Court of Human Rights (IACHR) sentenced that the Chilean State had violated the rights of equality and non-discrimination of a lesbian mother, Karen Atala,

Víctor Figueroa, Facultad de Humanidades y Ciencias Sociales, Universidad UNIACC, Santiago, Chile, and Department of Psychological Sciences, Birkbeck, University of London, United Kingdom; Fiona Tasker, Department of Psychological Sciences, Birkbeck, University of London, United Kingdom.

The article is part of the thesis submitted to obtain the PhD Degree in Psychology at Birkbeck, University of London, United Kingdom.

Correspondence concerning this article should be addressed to Víctor Figueroa, Facultad de Humanidades y Ciencias Sociales, Universidad UNIACC, Avda. Salvador 1200, Providencia, Santiago, Chile. E-mail: victor.figueroa@uniacc.cl 
who was separated from her two daughters (Corte Interamericana de Derechos Humanos, 2012). The IACHR ordered the Chilean State to make a public apology for a Chilean Supreme Court's ruling in 2004 and to recompose the damage caused to Karen and her daughters. For the first time, the Chilean State had to acknowledge the structural abuse exercised against LGBTQ people and to adopt an explicit nondiscriminatory stance.

After the IACHR's ruling, significant legal changes favouring LGBTQ people have occurred. These legal changes included the anti-discrimination law (2012), the addition of civil partnership (2015), and the approval of the gender identity law (2018). Thus, overall Chilean society has been moving slowly towards a more equalitarian legal context (Chile, Ministerio Secretaría General de Gobierno, 2012, July 12, 2015, April 13).

This new legal context in Chile has prompted further depathologising approaches toward homosexuality within social policy. For example, although same-gender couples cannot adopt a child together, the Chilean National Service for Children (SENAME) has stated that lesbians and gay men must not be discriminated against when applying to adopt a child as single parent and that they can be eligible as foster carers (Movimiento de Integración y Liberación Homosexual [MOVILH], 2015). However, adoption by heterosexual married couples remains SENAME's priority and adoption for single lesbians and gay men is still exceptional, locating same-gender couples in a disadvantaged political position, compared to heterosexual couples.

In this still disadvantaged legal context, Chilean LGBTQ organisations continue their battle to achieve more equal rights, focusing their efforts on the approval of same-sex marriage and same-sex adoption bills. Indeed, the same-sex marriage bill still has not been prioritised within the Parliament within the last two years. Further, although the Chamber of Deputies has already approved the same-sex adoption bill, its approval was delayed due to the pressures of right-wing groups and the strong opposition of an evangelical deputy.

\section{LGBTQ People Within Chilean Society}

According to population-based surveys, societal disapproval of sexual minoritis in Chile has steadily declined during recent years (Instituto de Investigación en Ciencias Sociales [ICSO], 2012; World Values Survey [WVS], 2006). For instance, according to a national public survey, the rate of people who agreed with the statement "homosexuality should be accepted" increased from 64\% in 2007 to 68\% in 2013 (Pew Research Center, 2013, June 4). Another national public survey indicated that the rate of acceptance was higher among younger than older people, with acceptance reaching $65 \%$ in the cohort aged between 18 and 29 years old (ICSO, 2012). These findings thus support the proposition that current generations of youth seem to be more tolerant toward sexual minority people in Chile than were previous ones.

Despite the increasing public approval of homosexuality in Chile, research has continued to record high levels of stigmatisation experienced by Chilean sexual minority groups (Barrientos et al., 2010; Gómez \& Barrientos, 2012). The Eighth Chilean National Survey of Youth, which interviewed 9,393 youths aged 15 to 29 years, indicated that the $15 \%$ of those who identified as "homosexual" reported experiencing discrimination within the previous month (Chile, Instituto Nacional de la Juventud [INJUV], 2017). Further, the Report of Human Rights of Sexual and Gender Diversity of the MOVILH (2018) revealed that in 2017 484 cases of discrimination were registered, including two murders, 56 acts of physical or verbal aggressions, 38 acts of discriminations in the workplace, and 30 education exclusions. In particular, the region of Bío Bío $(10 \%)$, where we conducted the present study, occupied the third place in terms of acts of discrimination, after Santiago (31\%) and Valparaíso (14\%).

Regarding public approval toward lesbian and gay (LG) parenting in Chile, a national survey of 1295 people revealed that only $36.1 \%$ endorsed the statement "lesbian couples are as good as heterosexual couples at rising children" (ICSO, 2012). Interestingly, the Eighth Chilean National Survey of Youth revealed that $28 \%$ of youth agreed with the statement "heterosexual couples do better in childrearing than homosexual couples", while $46 \%$ of youth disagreed with the same statement (INJUV, 2017).

Furthermore, a Chilean national survey revealed that $41 \%$ of people who identified as Catholic (56\% of the total sample) agreed with the right of homosexual couples to adopt children, as did only $23 \%$ of people who identified as Evangelical (14\% of the total sample; ICSO, 2014). This data suggests that LG parents and their children in Chile live in a predominantly non-supportive Christian sociocultural context.

A recent Chilean national survey showed that while Catholicism had decreased from $73 \%$ in 1998 to $55 \%$ in 2018, Evangelicalism had increased from $14 \%$ to $16 \%$ in the same period (Centro de Estudios Públicos, 2018). The same survey revealed that $80 \%$ of Chilean people reported believing in God in 2018 , a slight 
decrease from the $86 \%$ rate reported in 1998. Further, the Eighth Chilean National Survey of Youth revealed that $65 \%$ of youth identified as Catholic and $27 \%$ as Evangelic or Protestant (INJUV, 2017).

\section{Empirical Studies on Attitudes Toward LG Parenting}

LGBTQ psychologists have suggested that both, positivist and critical, approaches have much to offer in order to understand prejudice against LGBTQ people (Peel \& Riggs, 2016). Thus, our study is informed by both traditions, yet our study adopts a qualitative approach following a social constructionist perspective. Additionally, we address the proposition of Clarke, Ellis, Peel, and Riggs (2010), that suggests that LGBTQ psychology is a brand of psychology that affirms LGBTQ people and attempts to interrogate and challenge the prejudice and discrimination experienced and the privileged position of heterosexuality within psychology and society.

\section{Positivist Empirical Studies}

Research studies conducted in Western European countries and English-speaking countries have indicated associations between negative perceptions of LG parenting capabilities and developmental outcomes for children with prejudice against sexual minorities (Massey, Merriwether, \& Garcia, 2013). Additionally, studies have shown that being a man (Gato \& Fontaine, 2013), being older (Vecho \& Schneider, 2015), having a lower level of educational attainment (Averett, Strong-Blakeney, Nalavany, \& Ryan, 2011), holding conservative political ideologies (Perry \& Whitehead, 2015), believing homosexuality was not innate (Costa et al., 2014), holding Christian beliefs and practicing religion (Perry \& Whitehead, 2015), or having less contact with LG people (Costa, Pereira, \& Leal, 2015) were all associated with holding more negative attitudes toward LG parenting.

Only a few studies assessing attitudes toward LG parenting have been conducted in other cultural contexts, such as Latin America. For example, one study conducted in Chile revealed that being a man and/or holding traditional views on gender roles were associated with greater rejection of LG parenting (FríasNavarro, Barrientos-Delgado, Badenes-Rivera, Monterde-i-Bort, \& Cárdenas-Castro, 2013). The same study also revealed that contact with sexual minorities was inversely related to the rejection of LG parenting. Similarly, a Brazilian survey found that women and younger participants held less discriminatory attitudes toward LG parenting than did men and older participants (Reis et al., 2016).

\section{Social Constructionist Empirical Studies}

Only a few qualitative studies have explored heterosexual people's discourses or opinions about LG parenting. A landmark study conducted by Clarke (2001) analysed a variety of people's arguments against LG parenting, using data collected from six focus groups carried out with 44 undergraduate students at a United Kingdom university ( 37 women and seven men). In addition, Clarke also reviewed data from 116 media representations of LG parents (95 newspaper and magazine articles and 21 talk shows). Clarke's study revealed that participants' arguments stated or implied selfishness on the part of LG parents because they ignored the best interest of the child. Other ideas portrayed LG parenting as a sin (against Biblical prescriptions) or as something unnatural. Finally, other arguments implied that LG parents did not provide appropriate role models, that children of LG parents would grow up to be LG themselves, and/or that the children of LG parents would be bullied.

Subsequent qualitative studies, both in the United Kingdom (Hicks, 2005) and Australia (Pennington \& Knight, 2011), have revealed similar findings. In particular, the study conducted by Hicks (2005), which sampled social workers and managers participating in adoption and foster care assessments, indicated that gay fathers were thought of as a potential source of social perversion and sexual risk for children.

Only a few qualitative studies investigating heterosexual people's discourses or opinions on LG parenting have been conducted in Latin American countries. A study conducted in Rio de Janeiro, Brazil, with two judges, four social workers and five psychologists involved in adoption, found that some professionals expressed opposition to adoption by LG parents because parents would not provide children with differentgender role models (Uziel, 2001). Interestingly, a recent qualitative study conducted with 12 youths (aged 14 to 17 years old) in Colombia revealed contrasting findings (Camacho Ordóñez, Tarquino Bulla, Prado Guzmán, \& Preciado Céspedes, 2017). While a few participants reported that homosexual people should not 
be allowed to marry or adopt children, the majority of participants considered that the rights of homosexual people to marry or adopt should be respected.

\section{Theoretical Framework}

We understand discourses about LG parenting to be constructed through language and social interaction (Gergen, 1985). Additionally, we follow Clarke's (2002) and Hegarty's (2008) propositions of moving discourse analysis beyond the textual (Potter \& Wetherell, 1987) into the verbal, particularly with a focus on the content of the discourse (a thematic approach), which seeks to show the notions people have about social reality (Clarke \& Peel, 2008).

In the present study, we explored the discourses expressed by heterosexual women, who were psychology students, with a particular focus on the notions they have about LG parenting. Notwithstanding, we kept in mind that discourses may vary considerably among women, as intersectionality theory suggests (Warner \& Shields, 2013). Further, we studied psychology students, considering that as future psychologists these students may be involved in adoption and foster care evaluations and parenting skills assessments in Family Courts in Chile. As Uziel (2001) and Massey et al. (2013) have suggested, subtle forms of prejudice can be displayed by social service professionals during the adoption process.

Additionally, we examined the social reality of LG parenting through the lens of life course theory, which aims to reconcile divisions between essentialism and social constructionism (Hammack, 2005). Life course theory then seeks to integrate the conventional division of the body and the social environment. For instance, sexual orientation can be thought as a biological disposition to respond emotionally and sexuality to members of a particular gender, that can be manifested through sexual desire and expressed through behaviours and (sexual) identity (e.g., lesbian or gay) in a particular cultural context (Hammack, 2005).

A life course theory is particularly useful for the study of LG parenting, since it locates LG parents and their children within a wider sociocultural and historical context (Cohler, 2005). LG parented families are increasingly visible contemporary family types and by their visible presence alone continuously challenge heteronormative notions of the parenting, family, and couple relationships (Allen \& Demo, 1995; Demo \& Allen, 1996). Thus, we paid attention to the contextual reasoning heterosexual women gave in their discourses about LG parenting, in order to explore the prejudice that LG parents and their children have to cope with when socially navigating Chilean society. We focused particularly upon the role that religious or social discourses played within participants' understandings. Our research questions were: How do Chilean heterosexual women give meaning to LG parented families? What do heterosexual women think about children growing up with LG parents? What are the challenges or difficulties heterosexual women think LG parents and their children cope with in Chilean society? How do religious discourses of family, gender, and sexuality influence the views of Chilean heterosexual women on LG parenting?

\section{Method}

Our study is part of a larger research project focused on LG parenting in Chile, which interviewed lesbian mothers, lesbian, gay, and bisexual prospective parents, and psychology students as a part of a Doctoral research study.

\section{Participants}

We used convenience sampling as a technique for the recruitment. The sample for this study consisted of 15 heterosexual women aged between 24 to 45 years old $(M=32.6, S D=6.5)$, who enrolled as first-year psychology students on an evening university program. Both women and men were invited to participate in this study. However, only women volunteered to take part in the focus group (men in effect self-excluded themselves). Thus, given that only women took part in the focus groups, our current study focused on heterosexual women's views on LG parenting. Riessman (2002) has suggested that qualitative researchers are able to adapt the purpose of their studies following the circumstances of the fieldwork, especially when they work in underexplored areas. We considered no other inclusion criteria during recruitment.

The college was located in the city of Concepción, within the Bío Bío Region of Chile. Recruitment was conducted with the collaboration of a university's department of psychology. Participants enrolled in 
psychology courses were recruited by way of an oral invitation requesting participation given by the first author during an evening lecture.

Ten participants were single and five were married. Eleven participants lived within the borough of Concepcion and four lived within the neighbouring borough of Talcahuano. Six participants had previously completed undergraduate studies and nine were undertaking undergraduate studies for the first time. Nine participants reported having a religious affiliation (seven Catholic, one Christian, and one Evangelical), two mentioned that they simply had religious beliefs, and four stated no religious affiliation or beliefs. All 15 participants identified as middle-class and non-disabled women. A summary of each participant's details and the pseudonyms assigned to participants are listed in Table 1.

Table 1

Demographic Information on Participants

\begin{tabular}{cllllll}
\hline Focus group & $\begin{array}{c}\text { Participan } \\
\mathbf{t}\end{array}$ & Age & $\begin{array}{c}\text { City of } \\
\text { residence }\end{array}$ & Marital status & Educational level & Religion \\
\hline $\mathbf{1}$ & María & 37 & Concepción & Married & Bachelor & Catholic \\
$\mathbf{1}$ & Mónica & 37 & Concepción & Single & Bachelor & No \\
$\mathbf{1}$ & Rebeca & 38 & Concepción & Single & Bachelor & Yes \\
$\mathbf{2}$ & Chiara & 30 & Concepción & Married & Undergraduate student & Yes \\
$\mathbf{2}$ & Adriana & 29 & Talcahuano & Married & Undergraduate student & Catholic \\
$\mathbf{2}$ & Romina & 24 & Talcahuano & Single & Bachelor & No \\
$\mathbf{2}$ & Ester & 36 & Concepción & Single & Bachelor & Christian \\
$\mathbf{2}$ & Amparo & 34 & Talcahuano & Single & Undergraduate student & No \\
$\mathbf{2}$ & Marta & 24 & Concepción & Single & Undergraduate student & No \\
$\mathbf{2}$ & Tamara & 32 & Concepción & Single & Bachelor & Catholic \\
$\mathbf{3}$ & Pamela & 45 & Concepción & Married & Undergraduate student & Catholic \\
$\mathbf{3}$ & Elena & 28 & Talcahuano & Married & Undergraduate student & Evangelical \\
$\mathbf{3}$ & Amanda & 42 & Concepción & Single & Undergraduate student & Catholic \\
$\mathbf{3}$ & Cecilia & 27 & Concepción & Single & Undergraduate student & Catholic \\
$\mathbf{3}$ & Victoria & 26 & Concepción & Single & Undergraduate student & Catholic \\
\hline
\end{tabular}

\section{Instrument}

We used focus groups for data collection, as these have been promoted as a convenient research technique for collecting data from several people simultaneously and capitalise on group interaction when participants explore and expand upon each other's views (Kitzinger, 1995). Instead of asking a question to each person in turn, focus groups encourage people to talk to one another around the topic (Kitzinger, 1995). Therefore, we used focus groups to investigate heterosexual women's discourses about LG parenting through group discussions.

To contextualise our study concerning existing research, we developed a focus group schedule exploring participants' broad understandings of family definitions (e.g., Could you describe what a family is according to your views? What do you think the word family refers to? What makes a good family?) and their views on diverse family forms (e.g., Do you think children need a mother and a father? What difficulties can you imagine a single parent and her/his children facing?). In addition, some questions specifically examined participants' views on LG parenting (e.g., What difficulties can you imagine a lesbian/gay parent and her/his children facing? Can you imagine any advantages for children growing up in a lesbian/gay family?).

Three focus groups, each conducted in Spanish, were conducted during July 2014. Participants were asked to provide demographic information on a brief questionnaire, generating data on the variables listed in Table 1. 


\section{Procedure}

Our study procedure received prior approval from the Ethics Committee of the Department of Psychological Sciences in which the authors were based and endorsement from the university which hosted the focus groups.

We gave each participant a sheet with information about the purpose of the study. We asked them to sign an individual informed consent form. With each participant's consent signed, we audio-recorded the groups and then transcribed them by the first author.

Focus group ranged between 45 and 90 minutes in length.

Interview questions directly exposed participants' personal views related to LG parenting, a topic which might elicit divergent viewpoints. Thus, we observed participants' emotional states during the interview in order to stop it, if necessary. We also planned to grant back-up preliminary psychological support if required, to be provided by the first author with follow-up provision at the university's counselling service, if needed. The first author is a psychologist who had previous experience conducting research with lesbian, gay and bisexual people. We carried out each focus group as planned, without any problems occurring, and no participants required individual debriefing or requested counselling support from university services.

We conducted a careful procedure for confidential data storage and handling of information.

\section{Analysis}

Braun and Clarke (2006) suggested that thematic analysis (TA) can be a social constructionist method, because it examines how events, realities, meanings, and experiences reflect a range of discourses operating within society. We followed Braun and Clarke's (2006) six-stage model for conducting TA within psychology: First, we read several times each verbatim transcript from a focus group, noting down initial ideas. Second, we systematically compiled a set of initial codes across each focus group. Third, we collated codes into potential themes, selecting all the relevant data for each potential theme. Fourth, we created a primary thematic map with all the themes generated. Fifth, we refined the map of themes to create major themes and subthemes. Sixth, we wrote down the analysis of each theme and pushed on to a more interpretative level, by reviewing our research questions within a social constructionist perspective (Gergen, 1985). We initially carried out analyses in Spanish and only subsequently translated into English, in order to check the analysis with the second author. We present the result of the TA by highlighting the particular contribution of individual participants to the group discussion. In this sense, we follow the phenomenological proposal of Tomkins and Eatough (2010), which suggests that it is important not to lose the particular contribution of individual participants within the focus group, in order to account for their personal experiences or meanings.

\section{Results}

The TA generated the following themes, which we describe below with their constitutive subthemes: (a) Family structure: Moving beyond biological ties; (b) Parents and modelling: The importance of parental gender and sexual orientation for children's development; and (c) Family in social context: LG parents and their children being discriminated (see Table 2 for a summary of themes and constituent subthemes).

\section{Family Structure: Moving Beyond Biological Ties}

Participants' accounts revealed various understandings regarding family composition, detailing different types of family forms and not only those created by biological ties. Nevertheless, although participants described different family constellations, most interviewees implied that the ideal family model in Chilean society was the family formed by two parents of different genders. When participants described other families types (we used the term other families to refer collectively to all family types that were not headed by two parents of different genders), they mainly defined these other forms in reference to (or as moving beyond) the ideal family model. For example, Amparo said that there were different types of families, aside from a family model of a mother, a father and their children: 
Well, in Chile, as she [Romina] says, that's mainly the perception, father, mother and children, but there are other types of families... Married couples without children are also a family, or grandparents living with and raising their grandchildren are also a family. (Focus Group [FG] 2, Line [L] 17-21)

Table 2

Themes and Subthemes from Thematic Analysis

Themes and subthemes

a Family structure: Moving beyond biological ties

a.a. Moving beyond the ideal family with two parents of different genders

a.b. Valuing the family with two parents of different genders

b Parents and modelling: The importance of parental gender and sexual orientation for children's development

b.a. Children do, or do not, need different gender role models

b.b. (Not)accepting LG parents raising children in the absence of one gender role model

b.c. LG parents influencing, or not influencing, their children's sexual orientation

c Family in social context: LG parents and their children being discriminated against

c.a. Children of LG parents being discriminated against by their peers

c.b. LG parents being discriminated against by other adults

Moreover, all participants acknowledged that same-gender couples formed a particular type of family in Chilean society. Some participants also reported close contacts with families formed by non-heterosexual people. Tamara's narrative revealed how she held a positive view of her gay friends who formed a family:

For example, I have two friends who are gay... and they both are parents, one has a little boy and the other has a little girl, and they are a couple, and they take their children to their home over the weekend. So, their family is formed by my two friends, the daughter and the little boy, so they're a family. I don't know, I find it wonderful. (FG 2, L 172-176)

Despite participants recognise the existence of the other families in Chilean society, the value participants give to these varied and was often different to that given to the traditional "ideal" family. Thus, it is important to distinguish between participants' own understanding of family definition and participants' own personal views, or values, regarding family formation. Although all participants acknowledged that family configurations were diverse, not everyone gave a positive value to other families. Indeed, four participants (Romina, Pamela, Elena and Victoria) specifically indicated that the family formed by two different-gender parents was the ideal model for them. While stating or implying that other family forms fell short of this standard, Elena said that in her own view a family had to be formed by a man and a woman, who ideally should have children together:

Elena: For me a family consists of a father, a mother, and children if possible, otherwise... but always a father and a mother...

Cecilia: You mean the ideal family?

Elena: That's the family for me. (FG 3, L 4-7)

Interestingly, Pamela, Elena and Victoria also stated that this ideal two-parent of different-gender model was based on their Christian religious beliefs. Pamela implied that Jesus' family was the ideal family model for her:

As Victoria says... I think there is a religious idea, this model from Nazareth [Jesus' family]... At least I'm Catholic, so this is model, with a father [Joseph] and a mother [Mary]... (FG 3, L 84-85)

Further, it seemed that this Christian ideal family model was deemed incompatible with other family types, and in particular with family formation by same-gender couples. For instance, Elena said that two women were not "designed" to have children together as a man and a woman were. Elena's narrative clearly revealed her religious understandings of human reproduction and the linkage of biological parenthood with social parenting. Thus, alongside religion, biological parenthood often appeared important in the narratives of participants who supported a heteronormative ideal family model: 
FIGUEROA AND TASKER

Two women can't have a child, because they are not designed to have it, it has to be a man who has to join with a woman to produce a child. Then I am assuming that both [the man and the woman] will contribute with something different to form a family... But this is the ideal [family]. (FG 3, L 96-99)

\section{Parents and Modelling: The Importance of Parental Gender and Sexual Orientation for Children's Development}

Participants reflected on how modelling a same-gender parental relationship might impact upon children's development. In particular, interviewees discussed how parental gender and sexual orientation would affect children's gender or sexual development.

The most discussed aspect of parental modelling was how parental gender might affect children. Ten participants reported that children should have two different-gender role models and that the parental role during childrearing was associated with a parent's gender. Nevertheless, eight of the participants conveyed that gender role models need not necessarily be provided by the child's parents and that other family members (or relatives) could represent a gender model in the absence of a parental gender role model. Mónica conveyed that parental roles were associated with parental gender and said that she, as a woman, would not be able to teach certain things to a son. Mónica's account revealed how she saw feminine and masculine gender roles as essentially (and biologically) different, with this difference being reflected in parenting roles:

[Children need] a feminine and a masculine model who doesn't have to be the father and the mother, it may be the grandmother, it may be an aunt, it may be even a parent's close friend, because I think there are certain things that... Well, two women are not going to be able to teach a male child what a male model could... I'm not saying it's bad, not at all, but as a woman I can't... I'm talking about me, as a woman I can teach many things to my children, but there are things that are not within my feminine nature, I don't know how to explain it... (FG 1, L 247-253)

Although Mónica, in the extract we presented above, indicated that two lesbian mothers could not teach a son masculine things like a man could, she also implied that she did not hold a negative view on samegender couples raising children. Interestingly, six of the 10 participants who argued that children needed two different gender role models did not express any specifically negative views about lesbian and/or gay parents raising children. For instance, at another point in the focus group, Mónica said:

Which doesn't mean that the child can't be raised by two women or two men, but it must have a complement on that side. (FG 1, L 837-838)

In contrast with participants who indicated that children need two different parental gender role models, another four participants conveyed that children did not necessarily need to be raised with two different gender role models in the home. Nevertheless, while these participants were open about the possibility of children being raised without one type of gender role model, some traditional elements of gender role understanding were still visible in their narratives. Interestingly, three of these stories were given by participants who were themselves single mothers. Amanda argued that parents' gendered roles were socially defined and that she herself as a single mother fulfilled both gender roles in her child's upbringing. Amanda implied that her role in providing her daughter with affection and protection was different from her role of controlling her daughter's behaviour. Amanda also tried to convey that she felt more pressured in trying to fulfill these two different gendered roles, but she could with the support of her extended family. In the extract bellow Amanda conveyed that being a single parent was a difficult task for her as she needed to fulfill both gender roles. She implied that normally mothers were loving and not harsh and judgmental, but she has to do this, and because she sees herself as a normal mother/woman, this hurts her. Thus, as Amanda put it, the support of her own parents and the blessing of God helps her fulfill both feminine and masculine parental roles:

But basically it [gender role] is something social, I fulfill both [female and male] roles, thank God, obviously with the support of my parents, because I can work, I can study and I feel calm, because I know she's in good hands, but it really hurts me to come back home and reprehend my daughter when I have to fulfill the other role of affection and protection. (...) Sometimes that carries more burden, because sometimes one wouldn't like to reprehend or punish. I think the fact of educating her [Amanda's daughter] becomes heavier, well, not heavier, perhaps difficult, because you don't have a [male] partner to put the blame on each other. (FG 3, L 197-204)

The other four participants who implied that children needed two different gender role models expressed negative views regarding LG parents raising children, but these participants referred specifically to the absence of one gender or the presence of two parents of the same gender. Ester implied that being raised by two parents of the same gender might disrupt the child's sexual development. She also argued that gay parents might teach their children that non-traditional gender expressions are fine or something to be seen 
as normal. Ester's narrative revealed how she herself saw gender non-conforming behaviours as something pathological. Furthermore, gender and sexual identity were linked together in Ester's report, because she assumed that gay men will be able to be together through adopting complementary feminine and masculine gender roles:

The boy might not have the inclination [same-gender attraction], but this [having two fathers] might disrupt his sexuality, because actually these two men... Sometimes one is more feminine and the other is more masculine, so it will be pathological, because probably they are going to teach him that it's OK, that they liked each other, I don't know how they're going to explain that. (FG 2, L 733-736)

Participants who were against the idea of same-gender couples raising children because of the absence of a gender role model, also situated this within a traditional understanding of gender roles and argued that the lack of a gender model could have negative consequences on children's development. Pamela conveyed that men and women had gendered roles within the family context. She implied that women were generally better than men within the domestic context and that the man's role was outside home. In the extract below Pamela relied on her ideas concerning an ancestral gender division of labour within the family context. She also implied that men felt more detached from childcare, while the woman's key role was giving love to her children:

I'm thinking about the domestic sphere, sometimes women do... I think most women do it [domestic activities] better, why? For the [children's] upbringing, for many factors, I am talking about generally... the issue that men work outside home... It has been always thought that the man was outside [home] and the woman inside, so when she goes outside... Ask a father if he goes with his heart tightened when he leaves the child, there might be very few, because their role is outside... And he goes hunting, think about the ancestors, the man went hunting and the woman stayed inside. (...) I think dad gives something to his son, and the mother gives something different, the love. (FG 3, L 383-389)

Four participants expressed concern that LG parents could particularly affect their children's sexual orientation. Tamara said that because she did not herself have a clear idea of the origin of homosexuality, she was concerned about the possibility that children of gay parents could become homosexuals, as a consequence of parental sexual orientation. Tamara predicated her apprehension about the possibility of gay men adopting children, because that would affect the child's normal developmental pathway and make it deviate from expected heterosexuality. Tamara's worry followed on from Romina's argument that children imitate their parents:

Romina: Yes, because children always imitate their parents.

Tamara: I still believe that yet we aren't clear whether a homosexual is born or not, I think once... I have no problem with the issue of homosexuality, but I'm thinking about the issue of adoption among men. (...) We don't know if the child may be born normal and because he sees a homosexual relationship he can be guided and do the same in the future, which is what we... in my case, I wouldn't like it. (FG 2, L 485-493)

In contrast with the above accounts, five participants conveyed that LG parents would not affect children's sexual orientation development. Chiara implied that although parents might influence their children in some way, this did not necessarily mean that children would imitate their parents' sexual orientation. Similarly, Marta mentioned examples of gay fathers having heterosexual sons in order to convey that children's sexual orientation did not depend on parents' sexual preferences:

Chiara: I think it doesn't mean that the child wants to be like the parents, or to say "OK, because my dad is gay, I'm gonna be gay". No, I think the child is a child, and is independent, and a being apart.

Romina: But you always want to be just like your parents.

Marta: But there are cases where the father is gay and the son likes women.

Chiara: Obviously parents influence their children in some way, but the child can think autonomously. (FG 2 , L 742-748)

\section{Family in Social Context: LG Parents and their Children Being Discriminated}

Participants discussed how they thought other people would react toward LG parents and their children. In particular, most participants conveyed that LG parents and their children would be discriminated within the social context in which they lived.

The possibility of children of LG parents being discriminated as a consequence of parental sexual orientation was the major concern for most focus group participants. Indeed, 13 of the 15 participants reported that children of LG parents would be discriminated by their peers, because of their parents' sexuality. Some participants implied that children would be discriminated by school classmates and/or their neighbours. Romina conveyed that the children of gay fathers would likely be questioned about their family 
configuration, either by having two fathers or by not having a mother in the home. Similarly, Chiara reported that she was concerned about the discrimination children of LG parents would have to cope with in their social contexts:

Romina: They will grow up being discriminated by their classmates.

Chiara: Yes, that's what worries me.

Romina: Their neighbourhood friends, people will tell them "Why do you live with two fathers and don't have a mother?"

Chiara: There is an important issue here, and it's that children are cruel, they are so cruel.

Romina: Bullying today is so strong. (FG 2, L 347-352)

Furthermore, 10 out of 13 participants who said that children of LG parents would experience peer discrimination, also questioned the possibility of LG parents raising their own children. For instance, participants who disagreed with same-sex adoption in Chile argued that this was to avoid children being exposed to discrimination. In particular, three of these participants implied that discrimination might be harmful for children. The following focus group discussion indicates how participants opposed same-sex adoption legislation, because they thought Chilean society was not prepared to accept families headed by LG parents, although some participants struck a note of optimism for the future:

Interviewer: Do you think same-sex couples should adopt children?

Chiara: I don't think so.

Adriana: It's difficult.

Amparo: Not at the moment.

Marta: Sure, not at this time.

Tamara: No, we're not culturally ready for that yet.

Ester: For the sake of children, because we are not prepared as a society.

Tamara: I think from my son onwards people are going to have another view.

Adriana: I think so, but not now.

Ester: Because children have to understand, in general, everyone, not only the children who live that.

Romina: It would be harmful for children and that's not fair to them. (FG 2, L 695-703)

In contrast to participants who mentioned that discrimination would be harmful for children, three participants conveyed that discrimination would not necessarily be harmful for children. Interestingly, these participants also supported childrearing and adoption by same-gender couples. Cecilia implied that LG parents might overcome discrimination by providing their children with more supportive social contexts:

If parents overcome all the above, school, society... if they are able to raise the children in a context that respects them, people who understand their nuclear family, it shouldn't be a problem. (FG 3, L 568-570)

Furthermore, Mónica believed that children might themselves be able to find a supportive context in their school. Mónica mentioned that she had been working in a school where there were two lesbian mothers whose daughter did not experience peer discrimination. Mónica suggested that children might be taught from an early age about tolerance:

There was never an issue of discrimination or a problem with the girl. It was surprising for me, not shocking, but surprising, like "oh, that's crazy". I had never seen a family with two moms... But they (peers) were so adjusted, and they (peers) were so respectful about them, too. So, if children are taught from an early age, of course, the transition is more natural. (FG 1, L 309-314)

Eight participants reported that the LG parents themselves would be discriminated as consequence of their sexual orientation. These participants agreed that LG parents would be discriminated by other adults in contexts such as children's school and their neighbourhood. María, who did not support same-gender adoption in order to protect children from discrimination, also mentioned that the LG parents would experience discrimination. Specifically, María talked about the discrimination experience of her neighbour who was a lesbian mother with a female partner, although María was keen to distance herself from the discriminatory behaviours of others. Likewise, Rebeca, who supported same-gender adoption, added that LG parents would no doubt have to cope with social stigma at their children's school:

María: I have a [female] neighbour who separated [from her husband] and she's living with a female partner now and, for example, no one talks to them in the neighbourhood and I'm the only one who talks to them, it's the same for me, but everyone else says rude things to them.

Rebeca: It's the social stigma.

Mónica: The discrimination.

Rebeca: Yes, these [LG] parents will be observed when they go to a parents' meeting at the school.

María: They will be teased in the beginning.

Rebeca: Yes, by their neighbours, as you said... (FG 1, L 593-599) 


\section{Discussion}

Our study aimed to explore how Chilean heterosexual women, who were also psychology students, thought about LG parents raising children.

Although most participants held positive views about other families, a minority of participants gave a positive value only to the families formed by two parents of different genders.

It is interesting how some participants in our study conflated biological parenthood with social parenting and understood that only different-gender couples should have and raise their own biological children (see Golombok, 2015). Thus, in some regard participants portrayed same-gender couples as unable to parenting because they could not have their own biological children. Further, our findings revealed how Christian religious teaching regarding reproduction and parenting (Clarke, 2001; Perry \& Whitehead, 2015) continues to pervade some heterosexual women's assumptions about family formation in Chilean society.

Despite some participants' flexible understanding of parenting roles, most participants' general assumption was that children would best thrive in a traditional two heterosexual parent family (where gender roles would presumably complement each other). Participants' understandings thus reflect the significant importance most participants gave to gender role models as being synonymous with mothering and fathering and good childrearing. The importance of gender roles within Latino culture has been widely described in studies with Latino families (Zavella, 2003). In particular, Chilean society has been described as a strongly gendered society (Olavarría, 2001; Oyarzún, 2005; Valdés, 2005), in which the "naturalness" of gender roles permeates how people think about their gender, sexuality, and their roles within the family.

Additionally, a few participants reported some concerns regarding LG parents raising children, because of parents' non-conforming gender expressions (Clarke, 2001; Hicks, 2005; Pennington \& Knight, 2011). These participants saw any deviation from traditional gender roles as something "pathological" and believed that the children of LG parents might imitate their parents' "abnormal" gender behaviours. Furthermore, some interviewees implied that growing up with LG parents might disrupt children's sexual orientation development, an attitude previously described in other studies (Clarke, 2001; Pennington \& Knight, 2011). These participants thought that children might be born "normal" (heterosexual) and then become homosexual as a result of imitating their parents, a fear that reveals some participants' pathologising views about homosexuality.

Nonetheless, most participants did not question LG parents raising children simply because of parental gender or sexual orientation. As some participants implied, children of LG parents might be exposed to a wide range of gender models in their lives, for example, through interacting with teachers, babysitters, extended family members or parents' friends of different genders, as developmental scholars have also noted (Goldberg \& Gartrell, 2014; Tasker, 2010). Furthermore, some participants argued that LG parents would not affect their children' sexual orientation. Possibly, media interest in developmental studies on the outcomes of children of LG parents has played an essential role in guiding participants' understandings of children's gender and sexual orientation development (Saavedra \& Fuster, 2013, December 1).

What caused major concern to most participants when considering LG parenting was the possibility of children of LG parents being discriminated by their school classmates and/or their neighbours (Clarke, 2001; Pennington \& Knight, 2011). In this regard, some studies have suggested that stigma and bullying by peers might affect the well-being of children of lesbian mothers (Bos \& van Balen, 2008; Gartrell, Deck, Rodas, Peyser, \& Banks, 2005). Nevertheless, attending an LGBTQ supportive school and having positive parentchild relationships have been found to reduce the impact of stigma on children's well-being (Bos \& Gartrell, 2010; Bos, Gartrell, Peyser, \& van Balen, 2008). We consider that the assumption about children of LG parents experiencing victimisation by peers needs further empirical research, specifically in less investigated cultural contexts, such as Chile.

Finally, while most of the views expressed did not distinguish between LG parenting, some participants argued gay fathers would be more questioned about their family configuration than lesbian mothers. Research has shown that although lesbians and gay men can be stigmatised as parents, gay men often cope with more considerable suspicion, vigilance and discrimination because it is less common that men exercise as primary caregivers of a child, given the strong feminisation of care, particularly within Latino societies (Haces, 2006; Herrera, 2010, Herrera, Miranda, Pavicevic, \& Sciaraffia, 2018). 


\section{Conclusions}

Overall, our study revealed that most of the heterosexual women psychology students interviewed saw families headed by LG parents as a valid family form. Interestingly, participants' conservative opinions were more evident in the reports of participants who reported religious observance. Of the five participants who thought that LG parents were not appropriate models for children, two identified as Catholics, one as Evangelical and one as Christian. Nonetheless, the other five participants who also identified as Catholic did not express their view that growing up with LG parents would be detrimental for children's development. Thus, participants' rejection of LG parenting cannot be seen merely as a reflection of participants' religious observance, yet Christian religious teachings were drawn upon by participants' themselves when expressing homonegative views. This is particularly important considering the high rate of Christian religious belief still evident in Chilean society, even among younger generations.

Notwithstanding, we point out that the findings of this study represent understandings of LG parenting expressed by a small and diverse group of heterosexual women within a particular socio-historical time and context. Views of LG parenting might be substantially different among other groups of heterosexual women or as expressed by heterosexual men within Chilean society. Yet, considering the strong impact of religious and moral discourses on participants' understandings of LG parenting that we found, our findings might be valuable in understanding how sexual prejudice operates within mainstream Chilean (heterosexual) society. Also, our findings might help to illustrate how prejudice against LG parenting is constructed within a Christian religious sociocultural context, which in turn is a particular feature of Latino societies, despite their heterogeneity.

Following previous empirical research on attitudes toward LG parenting, we may expect that young women with a higher educational level, as participants in our study, might be more accepting of LG parenting than older women, with a lower educational level, and men. Thus, our findings are less applicable even for Chilean heterosexual women who do not fit with the essentially middle-class undergraduate young student features of the sample we select. It would be worth conducting further research with students who are beginning undergraduate studies in health or education. Furthermore, it might be relevant to examine the discourses of Chilean women of other generational cohorts, social class and educational level, and the discourses of heterosexual men across these different groupings. Moreover, it would be relevant to examine the experiences of children of Chilean lesbian mothers and gay fathers and the extent to which they are exposed to negative social forces and how these in turn might impact on children's well-being.

Interestingly, the interactive quality of focus group discussions allowed us to capture contrasting arguments for and against LG parenting among participants and to emphasize that seemingly inconsistent views were sometimes expressed by the same participants at different times within the focus groups. Indeed, Tomkins and Eatough (2010) have suggested that researchers working with focus groups within a phenomenological framework should appreciate how participants make sense of a phenomenon at that particular time, i.e. they are sharing different opinions or ideas within the context of a real-time discussion. For example, at the beginning of focus group discussion one participant stated that she was happy with her gay friends forming a family with their children, yet later, she argued against same-gender adoption because LG parents could disrupt a child's sexual orientation. Thus, hearing others' views may sway the discussion and presentation of views but it may, or may not, change ultimate viewpoints.

It is also worth highlighting the ambivalence present in participants' discourses and how prejudice operates differently according to participants' own life course stories and intersecting identities. For instance, some participants tried to portray themselves as accepting of LG parents at some point within the focus group, but in other occasions, they reported particular concerns regarding LG parents raising children, seeing homosexuality and gender non-conforming behaviours as a pathology that could negatively impact children's well-being. Furthermore, it is interesting to note that single mothers seemed to have a more flexible understanding of parents' (gender) roles than heterosexual married/partnered mothers, which might indicate that life course experiences and the intersection of different identities can impact upon people's understandings of parenting and gender roles.

Finally, our findings revealed that some participants saw homosexuality as an undesirable developmental outcome, showing underlying prejudice against non-heterosexuality. It also revealed participants' lack of awareness or denial of current research on gender and sexual orientation development. Studies that have compared children of lesbian mothers, gay fathers, and heterosexual parents indicate little 
or no difference across family types in children's gender-typed behaviours (Farr, Forssell, \& Patterson, 2010; Goldberg, Kashy, \& Smith, 2012) and sexual orientation (Gartrell, Bos, \& Goldberg, 2011; Golombok \& Tasker, 1996).

Thus, it would be worthwhile training Chilean psychology students about the development of children of LG parents and also highlighting subtle and enacted forms of sexual stigma. Finally, politicians and lawmakers should acknowledge that there is still much to do to reduce sexual prejudice in Chilean society and that LG parents and their children need specialised programs to attend their particular needs.

\section{References}

Allen, K. R. \& Demo D. H. (1995). The families of lesbians and gay men: A new frontier in family research. Journal of Marriage and Family, 57, 111-127. https://doi.org/10.2307/353821

Averett, P., Strong-Blakeney, A., Nalavany, B. A., \& Ryan, S. D. (2011). Adoptive parents' attitudes towards gay and lesbian adoption. Journal of GLBT Family Studies, 7, 30-48. https://doi.org/10.1080/1550428X.2011.537211

Barrientos, J., Silva, J., Catalan, S., Gómez, F., \& Longueira, J. (2010). Discrimination and victimization: Parade for lesbian, gay, bisexual, and transgender (LGBT) pride, in Chile. Journal of Homosexuality, 57, 760-775. https://doi.org/10.1080/00918369.2010.485880

Bos, H. \& Gartrell, N. (2010). Adolescents of the USA National Longitudinal Lesbian Family Study: Can family characteristics counteract the negative effects of stigmatization? Family Process, 49, 559-572. https://doi.org/10.1111/j.1545-5300.2010.01340.x

Bos, H. M. W., Gartrell, N. K., Peyser, H., \& van Balen, F. (2008). The USA National Longitudinal Lesbian Family Study (NLLFS): Homophobia, psychological adjustment, and protective factors. Journal of Lesbian Studies, 12, 455-471. https://doi.org/10.1080/10894160802278630

Bos, H. M. W. \& van Balen, F. (2008). Children in planned lesbian families: Stigmatisation, psychological adjustment and protective factors. Culture, Health \& Sexuality, 10, 221-236. https://doi.org/10.1080/13691050701601702

Braun, V. \& Clarke, V. (2006). Using thematic analysis in psychology. Qualitative Research in Psychology, 3, 77-101. https://doi.org/10.1191/1478088706qp063oa

Camacho Ordóñez, L. B., Tarquino Bulla, L. C., Prado Guzmán, K., \& Preciado Céspedes, A. L. (2017). Representaciones sociales de adolescentes sobre la homosexualidad, el matrimonio entre personas del mismo sexo y la adopción homoparental. Metamorfosis: Revista del Centro Reina Sofía sobre Adolescencia y Juventud, 6, 76-96. Retrieved from https://dialnet.unirioja.es/servlet/articulo?codigo=6163194

Centro de Estudios Públicos (2018). Estudio Nacional de Opinión Pública, Octubre-Noviembre 2018. Santiago, Chile: Author. Retrieved from https://www.cepchile.cl/cep/site/artic/20181218/asocfile/20181218093906/encuestacep_oct_nov2018_te_religion.pdf

Chile, Instituto Nacional de la Juventud (2017). $8^{\text {va }}$ Encuesta Nacional de Juventud 2015. Santiago, Chile: Author. Retrieved from http://www.injuv.gob.cl/storage/docs/Libro_Octava_Encuesta_Nacional_de_Juventud.pdf

Chile, Ministerio Secretaría General de Gobierno (2012, July 12). Ley N²0.609: establece medidas contra la discriminación. Santiago, Chile: Congreso Nacional de Chile. Retrieved from https://www.leychile.cl/Navegar?idNorma=1042092

Chile, Ministerio Secretaría General de Gobierno (2015, April 13). Ley $N^{\circ} 20.830$ : crea el acuerdo de unión civil. Santiago, Chile: Congreso Nacional de Chile. Retrieved from http://www.leychile.cl/Navegar?idNorma=1075210

Clarke, V. (2001). What about the children? arguments against lesbian and gay parenting. Women's Studies International Forum, 24, 555-570. https://doi.org/10.1016/S0277-5395(01)00193-5

Clarke, V. (2002). Resistance and normalization in the construction of lesbian and gay families: A discursive analysis. In A. Coyle \& C. Kitzinger (Eds.), Lesbian \& gay psychology: New perspectives (2 ${ }^{\text {nd }}$ ed., pp. 98-116). Oxford, United Kingdom: Blackwell.

Clarke, V., Ellis, S. J., Peel, E., \& Riggs, D. W. (2010). Lesbian, gay, bisexual, trans and queer psychology: An introduction. Cambridge, United Kingdom: Cambridge University Press.

Clarke, V. \& Peel, E. (2008). Introducing out in psychology. In V. Clarke \& E. Peel (Eds.), Out in psychology: Lesbian, gay, bisexual, trans and queer perspectives (pp. 1-9). West Sussex, United Kingdom: John Wiley \& Sons.

Cohler, B. J. (2005). Life course social science perspectives on the GLBT family. Journal of GLBT Family Studies, 1(1), 69-95. https://doi.org/10.1300/J461v01n01_06

Contardo, Ó. (2011). Raro: una historia gay de Chile. Santiago, Chile: Planeta.

Corte Interamericana de Derechos Humanos (2012). Caso Atala Riffo y niñas vs. Chile. Sentencia de 24 de febrero de 2012 (fondo, reparaciones y costas). San José, Costa Rica: Author. Retrieved from http://corteidh.or.cr/docs/casos/articulos/seriec_239_esp.pdf

Costa, P. A, Almeida, R., Anselmo, C., Ferreira, A., Pereira, H., \& Leal, I. (2014). University students' attitudes toward same-sex parenting and gay and lesbian rights in Portugal. Journal of Homosexuality, 61, 1667-1686. https://doi.org/10.1080/00918369.2014.951253

Costa, P. A., Pereira, H., \& Leal, I. (2015). "The contact hypothesis" and attitudes toward same-sex parenting. Sexuality Research and Social Policy, 12, 125-136. https://doi.org/10.1007/s13178-014-0171-8

Demo, D. H. \& Allen, K. R. (1996). Diversity within lesbian and gay families: Challenges and implications for family theory and research. Journal of Social and Personal Relationships, 13, 415-434. https://doi.org/10.1177/0265407596133007

Encarnación, O. G. (2011). Latin America's gay rights revolution. Journal of Democracy, 22(2), 104-118. https://doi.org/10.1353/jod.2011.0029

Farr, R. H., Forssell, S. L., \& Patterson, C. J. (2010). Parenting and child development in adoptive families: Does parental sexual orientation matter? Applied Developmental Science, 14, 164-178. https://doi.org/10.1080/10888691.2010.500958

Frías-Navarro, D., Barrientos-Delgado, J., Badenes-Rivera, L., Monterde-i-Bort, H., \& Cárdenas-Castro, M. (2013). Sex differences in sexual prejudice. Contact as mediator variable. European Journal of Child Development, Education and Psychopathology, 1, 45-58. https://doi.org/10.1017/sjp.2014.5

Gartrell, N. K., Bos, H. M. W., \& Goldberg, N. G. (2011). Adolescents of the U.S. National Longitudinal Lesbian Family Study: Sexual orientation, sexual behavior, and sexual risk exposure. Archives of Sexual Behavior, 40, 1199-1209. https://doi.org/10.1007/s10508-010-9692-2

Gartrell, N., Deck, A., Rodas, C., Peyser, H., \& Banks, A. (2005). The National Lesbian Family Study: 4. Interviews with the 10-yearold children. American Journal of Orthopsychiatry, 75, 518-524. https://doi.org/10.1037/0002-9432.75.4.518

Gato, J. \& Fontaine, A. M. (2013). Anticipation of the sexual and gender development of children adopted by same-sex couples. International Journal of Psychology, 48, 244-253. https://doi.org/10.1080/00207594.2011.645484 
Gergen, K. J. (1985). The social constructionist movement in modern psychology. American Psychologist, 40, $266-275$. https://doi.org/10.1037/0003-066X.40.3.266

Goldberg, A. E. \& Gartrell, N. K. (2014). LGB-parent families: The current state of the research and directions for the future. Advances in Child Development and Behavior, 46, 57-88. https://doi.org/10.1016/B978-0-12-800285-8.00003-0

Goldberg, A. E., Kashy, D. A., \& Smith, J. Z. (2012). Gender-typed play behavior in early childhood: Adopted children with lesbian, gay, and heterosexual parents. Sex Roles, 67, 503-515. https://doi.org/10.1007/s11199-012-0198-3

Golombok, S. (2015). Modern families: Parents and children in new family forms. Cambridge, United Kingdom: Cambridge University Press. https://doi.org/10.1017/CBO9781107295377

Golombok, S. \& Tasker, F. (1996). Do parents influence the sexual orientation of their children? Findings from a longitudinal study of lesbian families. Developmental Psychology, 32, 3-11. https://doi.org/10.1037/0012-1649.32.1.3

Gómez, F. \& Barrientos, J. (2012). Efectos del prejuicio sexual en la salud mental de gays y lesbianas, en la ciudad de Antofagasta, Chile. Sexualidad, Salud y Sociedad, 10, 100-123. https://doi.org/10.1590/S1984-64872012000400005

Haces Velasco, M. Á. (2006). Significado y ejercicio de los roles parentales entre varones homosexuales. La Ventana: Revista de Estudios de Género, 3(23), 127-165. Retrieved from https://doi.org/10.1017/CBO9781107295377

Hammack, P. L. (2005). The life course development of human sexual orientation: An integrative paradigm. Human Development, 48, 267-290. https://doi.org/10.1159/000086872

Hegarty, P. (2008). What comes after discourse analysis for LGBTQ psychology? In V. Clarke \& E. Peel (Eds.), Out in psychology: Lesbian, gay, bisexual, trans and queer perspectives (pp. 41-57). West Sussex, United Kingdom: John Wiley \& Sons.

Herrera, F. (2010). Develando prejuicios: ¿por qué los hombres homosexuales son padres de segunda categoría? Revista Estudos Feministas, 18, 265-267. https://doi.org/10.1590/S0104-026X2010000100017

Herrera, F., Miranda, C., Pavicevic, Y., \& Sciaraffia, V. (2018). "Soy un papá súper normal": experiencias parentales de hombres gay en Chile. Polis, 17(50), 111-137. https://doi.org/10.4067/S0718-65682018000200111

Hicks, S. (2005). Is gay parenting bad for kids? Responding to the 'very idea of difference' in research on lesbian and gay parents. Sexualities, 8, 153-168. https://doi.org/10.1177/1363460705050852

Instituto de Investigación en Ciencias Sociales (2012). Encuesta Nacional UDP. (Capítulo 5). Santiago, Chile: Universidad Diego Portales. Retrieved from http://www.encuesta.udp.cl/descargas/banco\%20de\%20datos/2012/Tablas\%20UDP\%202012.xls

Instituto de Investigación en Ciencias Sociales (2014). Religión y política en Chile: tendencias Encuesta Nacional UDP 2005-2015. Santiago, Chile: Universidad Diego Portales, Author. Retrieved from http://encuesta.udp.cl/descargas/publicaciones/2015/Religion\%20y\%20politica.pdf

Jones, D. \& Vaggione, J. M. (2013). Los vínculos entre religión y política a la luz del debate sobre matrimonio para parejas del mismo sexo en Argentina. Civitas - Revista de Ciências Sociais, 12, 522-537. https://doi.org/10.15448/1984-7289.2012.3.13050

Kitzinger, J. (1995). Qualitative research. Introducing focus groups. BMJ: British Medical Journal, 311(7000), 299-302. https://doi.org/10.1136/bmj.311.7000.299

Massey, S. G., Merriwether, A. M., \& Garcia, J. R. (2013). Modern prejudice and same-sex parenting: Shifting judgments in positive and negative parenting situations. Journal of GLBT Family Studies, 9, 129-151. https://doi.org/10.1080/1550428X.2013.765257

Movimiento de Integración y Liberación Homosexual (2015). Sename y adopción homoparental: "Lo importante es buscar los mejores padres, no discriminar". Santiago, Chile: Author. Retrieved from http://www.movilh.cl/sename-y-adopcion-homoparental-loimportante-es-buscar-los-mejores-padres-no-discriminar/

Movimiento de Integración y Liberación Homosexual (2018). XVI Informe Anual de Derechos Humanos: diversidad sexual y de género en Chile. Hechos 2017. Santiago, Chile: Author. Retrieved from http://www.movih.cl/documentacion/2018/Informe-DDHH-2017Movilh.pdf

Olavarría, J. (2001). Y todos querían ser (buenos) padres. Varones de Santiago de Chile en conflicto. Santiago, Chile: Facultad Latinoamericana de Ciencias Sociales.

Oyarzún, K. (2005). Ideologema de la familia: género, vida privada y trabajo en Chile, 2000-2003. In T. Valdés \& X. Valdés (Eds.), Familia y vida privada: ¿̇transformaciones, tensiones, resistencias y nuevos sentidos? (pp. 277-310). Santiago, Chile: Facultad Latinoamericana de Ciencias Sociales.

Peel, E. \& Riggs, D. W. (2016). Lesbian, gay, bisexual, and transgender psychologies. In N. A. Naples, (Ed.), The Wiley Blackwell encyclopedia of gender and sexuality studies (Vol. 4, pp. 1-6). London, United Kingdom: John Wiley \& Sons. https://doi.org/10.1002/9781118663219.wbegss137

Pennington, J. \& Knight, T. (2011). Through the lens of hetero-normative assumptions: Re-thinking attitudes towards gay parenting. Culture, Health \& Sexuality, 13(1), 59-72. https://doi.org/10.1080/13691058.2010.519049

Perry, S. L. \& Whitehead, A. L. (2015). Same-sex adoption as a welfare alternative? Conservatism, neoliberal values, and support for adoption by same-sex couples. Journal of Homosexuality, 62, 1722-1745. https://doi.org/10.1080/00918369.2015.1078209

Pew Research Center (2013, June 4). The global divide on homosexuality. Greater acceptance in more secular and affluent countries. Washington, DC: Author, Global, Publications. Retrieved from http://www.pewglobal.org/2013/06/04/the-global-divide-on-homosexuality/

Potter, J. \& Wetherell, M. (1987). Discourse and social psychology: Beyond attitudes and behaviour. London, United Kingdom: SAGE.

Reis, M., Ramiro, L., Tomé, G., Fischer, R., Neufeld, C. B., \& Gaspar de Matos, M. (2016). A identidade de género e a influência das atitudes face à homossexualidade/homoparentalidade entre luso-brasileiros [Gender identity and the influence of attitudes towards homosexuality/homoparenting among Luso-Brazilians]. Psicologia, Saúde \& Doenças, 17, 311-325. https://doi.org/10.15309/16psd170301

Riessman, C. K. (2002). Positioning gender identity in narratives of infertility: South Indian women's lives in context. In M. Inhorn \& F. van Balen (Eds.), Infertility around the globe: New thinking on childlessness, gender, and reproductive technologies (pp. 152-170). Oakland, CA: University of California Press.

Saavedra, C. \& Fuster, D. (2013, December 1). Familias homosexuales, contra viento y marea. Televisión Nacional de Chile, 24 Horas, Programas, Informe Especial. Retrieved from http://www.24horas.cl/programas/informeespecial/informe-especial-familiashomosexuales-contra-viento-y-marea-962593

Tasker, F. (2010). Same-sex parenting and child development: Reviewing the contribution of parental gender. Journal of Marriage and Family, 72, 35-40. https://doi.org/10.1111/j.1741-3737.2009.00681.x

Tomkins, L. \& Eatough, V. (2010). Reflecting on the use of IPA with focus groups: Pitfalls and potentials. Qualitative Research in Psychology, 7, 244-262. https://doi.org/10.1080/14780880903121491

Uziel, A. P. (2001). Homosexuality and adoption in Brazil. Reproductive Health Matters, 9(18), 34-42. https://doi.org/10.1016/S09688080(01)90087-4 
Valdés, T. (2005). ¿Del deber al placer? Socialización en sexualidad en familias populares de Santiago. In T. Valdés \& X. Valdés (Eds.), Familia y vida privada: ¿transformaciones, tensiones, resistencias y nuevos sentidos? (pp. 277-310). Santiago, Chile: Facultad Latinoamericana de Ciencias Sociales.

Vecho, O. \& Schneider, B. (2015). Attitudes envers l'homoparentalité: Une comparaison entre psychologues français et québécois [Attitudes toward gay and lesbian parents: A comparison among French and Quebec psychologists]. Revue Canadienne des Sciences du Comportement, 47, 102-112. https://doi.org/10.1037/a0037607

Warner, L. R. \& Shields, S. A. (2013). The intersections of sexuality, gender, and race: Identity research at the crossroads. Sex Roles, 68 , 803-810. https://doi.org/10.1007/s11199-013-0281-4

World Values Survey (2006). Official data file. Stockholm, Sweden: Author. Retrieved from http:// www.worldvaluessurvey.org

Zavella, P. (2003). "Playing with fire": The gendered construction of Chicana/Mexicana sexuality. In M. C. Gutmann, F. V. Matos Rodríguez, L. Stephen, \& P. Zavella (Eds.), Perspectives on Las Américas: A reader in culture, history, and representation (global perspectives) (pp. 229-244). Malden, MA: Blackwell.

Fecha de recepción: Noviembre de 2018.

Fecha de aceptación: Agosto de 2019. 